\title{
The Role of the West Java Indonesian Broadcasting Commission (KPID) in Preventing Citizen Panic Related to News and Information Regarding Covid-19
}

\author{
${ }^{1}$ Yadi Supriadi, ${ }^{2}$ M. Subur Drajat, ${ }^{3}$ Nuril Lutfiah Saleh, ${ }^{4}$ Anisa Suci R., ${ }^{5}$ Audi Siti Nur Huda \\ Fakultas Ilmu Komunikasi, Universitas Islam Bandung, Jl. Tamansari No. 1, Bandung, Indonesia \\ E-mail: ${ }^{1}$ supriadi@unisba.ac.id, ${ }^{2}$ msuburdrajat@gmail.com, ${ }^{3}$ nurlutsal@gmail.com, \\ 4asnisasuci.30@gmail.com, ${ }^{5}$ audisitinurhuda@gmail.com
}

\begin{abstract}
The distribution of news and information about Covid-19 occurred amid a pandemic. It certainly creates a panic impact on some people, especially those who do not have adequate media literacy skills. This panic leads to uncontrolled behavior and unfiltered acceptance of information. This study seeks to investigate how the West Java Regional Indonesian Broadcasting Commission (KPID) Role in Preventing Citizen Panic Regarding News and Information Regarding Covid-19. Official broadcast media with high credibility have often ignored because people tend to prefer media with high accessibility, such as the internet and social media. From this condition, news and information about Covid-19 have often mixed with hoaxes readily accepted by some people. This research uses qualitative methods with case study research, with data collection techniques carried out through interviews, literature study, and observation. The results showed that in overcoming public panic, KPID West Java encourages broadcast media to always pay attention to the Broadcasting Code of Conduct and Broadcast Program Standards (P3SPS) and health protocols in every broadcasting activity. Also, media literacy has consistently remained calm and aware of various hoax information, such as Covid-19.
\end{abstract}

Keywords: Information, Media Literacy, Panic, Hoax

\section{INTRODUCTION}

Coronavirus disease is devastating to the world. Information about the coronavirus began to develop and has since it first appeared in Wuhan City, China, been reported on December 31, 2019 (Buana 2020). Initially, the Indonesian government was optimistic that Covid-19 attacked no Indonesian citizen until March 2, 2020, President Joko Widodo officially announced a corona positive patient. Two Depok residents tested positive for corona; according to the Government Spokesperson for the handling of Covid-19, they had imported case status. According to the Centers for Disease Control and Prevention (CDC) in the United States, imported cases are cases where plague sufferers have infected outside their home country.
Coronavirus harms the health of the human body. It started when the spread of Covid 19 was the carrier. People contaminated by this virus will spread the virus to other humans through objects they have touched, air, and people who have had direct contact with Covid-19 sufferers. Also, the symptoms of people detected with this virus will experience flu, coughing, dizziness, fever, nausea, shortness of breath, weakness, fatigue, such as colds, and damage to the lungs (Yono, Rusmana, and Noviyanti, 2020). The Center for Disease Control and Prevention (CDC) provides information that the symptoms caused by this coronavirus are fever, fatigue, dry cough, muscle aches, and shortness of breath. As we know that shortness of breath is one of the most prominent characteristics of 
people exposed to this virus (Joharudin et al., 2020)

Since Indonesian citizens have been declared and exposed to the corona, almost every day, Covid-19 news has appeared in the mass media; in newspaper headlines, television talk shows, online news pages, radio broadcasts, to trending topics on social media. This news regarding the coronavirus increases public awareness in preventing and overcoming the dangers of the virus. The flood of information on the coronavirus has also led the public into a maze of information. Cases related to coronavirus traffic are widespread and distributed through the internet (web or blog) and social media. According to the Kominfo cyber drone, the first hoax appeared on May 6, 2019; then, 54 others occurred from January 23 to February 3 , 2020

Internet and social media consumption is increasing day by day (Taufik and Suhaeri, 2020). It has worsened the process of receiving information from the public. Individual participation in producing and distributing information is increasing, facilitated by various new media facilities such as blogs, WhatsApp, Facebook, Instagram, Twitter, Youtube, and other application systems (Taufik and Suhaeri, 2020). The need for the internet and social media is inevitable in various fields, including the health sector. Communication increasingly relies on online communication to exchange information and support resources, including health equipment, health management, health personnel, and information during a Covid-19 pandemic crisis. Social media is a place to get advice from peers who may be experiencing the same health problems. They also seek advice for making lifestyle changes and solutions to health problems they may be experiencing. For example, someone who cares about covid-19 prevention through handwashing with soap can search blogs or ask members of the social media community for advice. They are trying to ease concerns about covid by accessing and/or creating social media contexts about the handwashing movement's effectiveness in using soap to kill the covid-19 virus (Sampurno, Kusumandyoko, and Islam, 2020).

The Covid-19 outbreak, on the other hand, gave rise to what WHO calls an infodemic (Julie \& Kalina, 2020). Infodemics spread faster than the pandemic itself, with escalating damage in toxic information damaging the information ecosystem. In this situation, valid information has mixed misinformation/hoax/disinformation. As a result, it is not easy to carry out education by providing correct information (Astuti, 2020).

The flood of information related to Covid-19, both factual and hoax, has caused some Indonesians to panic. One of the panic behaviors that occurs is panic buying. People have flocked to buy enormous quantities of several commodities closely related to the prevention of Covid-19. Call it masks, antiseptics, medicines, even some food is purchased as stock to get a sense of security. Anxiety or Panic syndrome occurs when something goes beyond our thinking limits so that our bodies experience excessive shock symptoms. This panic syndrome causes many fear and anxiety in each individual (Joharudin et al., 2020).

Panic arises various stigmas, such as negative stigma against Covid-19 sufferers, towards Covid-19 corpses, towards people who have just returned from out of town or abroad, and also the stigma against families with Covid-19 sufferers. We also believe that the public's lack of information from the authorities and the spread of fake news has also affected panic buying (Shadiqi et al., 2020). 
Yadi Supriadi, dkk. The Role of the West Java Indonesian Broadcasting Commission...

The Indonesian government's efforts to deal with Covid-19 continue to have made through various health appeals and travel warning policies, up to the Large-Scale Social Restrictions (PSBB) stage. Besides that, the media also have an essential role in maintaining society's calm in a still vigilant condition with the information they convey. The fast movement to obtain and disseminate information has become a characteristic of the mass media. However, both television and radio should not only move to get 'interesting' news angles, such as the number of deaths, conflicts, and people's rejection of the corpse of Covid, especially news that contains political bias (Astuti, 2020).

According to McQuail, media has become a dominant source for individuals to obtain images and images of social reality and society and groups collectively. The media also presents normative values and judgments mixed with news and entertainment (Sarwono, 2013). Through this power, the media can play a significant role during the Covid-19 pandemic by presenting various information; apart from following journalistic corridors, it can also raise enthusiasm and minimize public panic.

Because of this, the Indonesian Broadcasting Commission (KPI) and the Regional Indonesian Broadcasting Commission (KPID) in various provinces play a significant role in being a 'broadcast referee' so that the information conveyed by the mass media about Covid-19 is following facts, is not misleading, and is free from hoaxes. It is also inseparable for West Java KPID to continue to monitor broadcasting during the Covid-19 pandemic so that the public remains calm in a state of vigilance.

Covid-19 is exciting research, especially in communication science, such as research conducted by Sampurno, Kusumandyoko, and Islam (2020). It regards people's behavior in using social media amid the Covid-19 pandemic, Ardiyanti's research (2020) on effective communication media in conveying Covid-19 information Yudhaswara and Hidayat (2020) which presents research on people's selective behavior in choosing covid-19 information in the mass media.

Meanwhile, researchers conducted research related to West Java KPID in preventing public panic amid Covid-19. It has focused on; (1) West Java KPID's steps in monitoring news and information related to Covid-19 and (2) West Java KPID efforts to provide media literacy so that people remain calm during the Covid-19 pandemic.

Based on Law no. 32/2002 concerning broadcasting, the Indonesian Broadcasting Commission is an independent state institution at the central and regional levels whose duties and authorities have regulated this law as a form of public participation in the broadcasting sector. This institution has the authority, among others, to set standards for broadcast programs, formulate regulations and establish guidelines for broadcasting behavior, supervise and impose sanctions on violators. In the condition of an anxious, panicked, and many worries caused by the Covid-19 pandemic, in line with this law, the broadcasting commission has the duty and obligation to ensure that the public gets accurate and correct information following human rights.

According to Mutmainnah (2019), Law no. 32/22002 concerning broadcasting has determined that the primary regulator of broadcasting is KPI and not the government. This law carries the spirit of democratization because it puts broadcasting sovereignty in the public's hands (through KPI), in line with broadcasting media that operates using broadcast frequencies that belong to the public. 


\section{METHOD}

This research uses qualitative methods with the type of case study research. According to Rakhmat and Ibrahim (2016), qualitative research's main objective is to create, expand, and sharpen theories by observing and interacting with humans and their natural environment to reveal rich and unique explanations. According to Creswell (2002), a case study is a study that places something or the object under study as a case. An object can be appointed if the object can have viewed as a system bounded by the object's time and place of occurrence. Meanwhile, according to Yin (2003), a case study is a research method that investigates contemporary phenomena in real life, which has carried out when the boundaries between the phenomenon and its context are not clear, using various data sources.

Data collection carries on literature study, observation, and interviews - a literature study obtained through books, journals, websites related to research problems - observations made on observing the West Java KPID. Then, carrying out its broadcast monitoring function at the West Java KPID Office, Jl. Malabar, Malabar, Kec. Lengkong, Bandung City. Observations carried on observing news about Covid-19 on television and radio from April to August 2020.

In interviews, there were respondents and informants. Respondents are people who will have interviewed once, while informants are people who will be interviewed more than once or also known as critical informants (Ardianto, 2011). In this study, the key informant was the Chairman of West Java KPID, Dedeh Fardiah, with the interview process three times. Meanwhile, an additional resource person is Santi Indra Astuti, anti-hoax activist Mafindo (Indonesian Anti-Defamation Society).

\section{RESULTS AND DISCUSSION}

On March 2, 2020, President Joko Widodo officially announced that Covid-19 had entered Indonesia; the level of news about Covid-19 in various media has begun to spread, both on television, radio, newspapers, especially on social media. It takes various forms, from direct news (straight news), talk shows to press conferences of the Task Force for the Acceleration of Handling Covid-19, which airs with various data findings.

From observations, the frequency of news and information about Covid-19 in the media has increased sharply until the period when the government imposes Large-Scale Social Restrictions (PSBB) through Government Regulation Number 21 of 2020 . The high level of news and information about Covid-19 can encourage the public to be vigilant, but on the other hand, panic is a side effect that cannot have avoided. According to McQuail, media has become a dominant source for individuals to obtain images and images of social reality and society and groups collectively, the media also presents normative values and judgments mixed with news and entertainment (Sarwono, 2015). The news and information that researchers group based on observations from April to August 2020 are as shown on TABLE 1.

The information received by the public is certainly not only through television and radio. Social media is a space with high accessibility to get information, but often it is mixed with hoaxes. Hoax focuses on belief rather than argumentation and feelings rather than deduction. They work by relying on prejudice, polarization, and identity politics, as well as belief, cynicism, and the individual's search for simple understanding in the face of complexity and profound change. The contamination spreads in text, images, video, and sound (Posetti \& Bontcheva, 2020). 
Yadi Supriadi, dkk. The Role of the West Java Indonesian Broadcasting Commission...

TABLE 1. News and Information Categorization Regarding Covid-19

\begin{tabular}{|c|c|}
\hline $\begin{array}{c}\text { Form of } \\
\text { Information }\end{array}$ & Information Content \\
\hline News & $\begin{array}{l}\text { Covid-19 cases in various regions in Indonesia Community } \\
\text { dynamics during the pandemic (Covid positive funeral conflicts, } \\
\text { panic buying, and the impact of the pandemic on various } \\
\text { aspects.) } \\
\text { Prevention efforts against Covid-19 }\end{array}$ \\
\hline Talks Show & $\begin{array}{l}\text { Government policies related to PSBB, AKB } \\
\text { The seriousness of the government in handling Covid } \\
\text { Covid prevention of budget oversight } \\
\text { economic and educational activities during the AKB period }\end{array}$ \\
\hline Press conference & $\begin{array}{l}\text { The official report of the Covid-19 Task Force on the } \\
\text { development of Covid-19 } \\
\text { Presidential statements regarding various government policies in } \\
\text { handling Covid-19 }\end{array}$ \\
\hline $\begin{array}{l}\text { Public service } \\
\text { Advertisement }\end{array}$ & $\begin{array}{l}\text { Campaign Against Covid-19 } \\
\text { Social distancing and Stay at Home advice }\end{array}$ \\
\hline $\begin{array}{l}\text { Commercial } \\
\text { Advertising }\end{array}$ & $\begin{array}{l}\text { Offers of food, beverage, and medicinal products accompanied } \\
\text { by information about the prevention of Covid-19 }\end{array}$ \\
\hline
\end{tabular}

Source: observational data April to August 2020

According to Posetti \& Bontcheva, hoaxes about Covid-19 or what they call dis-infodemics to consist of several forms, including; (1) emotional construction regarding false claims in the form of a narrative that has often mixed between incomplete information, personal opinions, along with elements of truth, (2) a narrative that has deliberately altered, created, and decontextualized which has designed to create confusion and arouse emotionally (3) the spread of fake or questionable websites or websites that display information in the form of news. (4) infiltration of information carried out to sow discord - relating to political agendas - as part of organized disinformation. Here are some examples of hoax news and information about Covid-19 that were officially collected by the central government's Covid-19 Handling Task Force (see TABLE 2).

News and information spread through mass media and social media certainly have an extraordinary effect. According to Cangara (2012), there are three dimensions of mass communication effects: cognitive, affective, behavioral, or conative. Cognitive effects include increased awareness, learning, and additional knowledge. Affective effects are related to emotions, feelings, and attitudes. Meanwhile, behavioral or conative relates to behavior and intention to do something in a certain way. Cognitively, the mass media encourages the public to continue to be aware of the dangers of Covid-19. It then leads to a conative effect where people try to comply with various health protocols recommended by the government, such as washing hands, using masks, and maintaining distance.

Meanwhile, the conative effect is an area where each individual is different in responding to news and information 
TABLE 2. Examples of Hoax News and Information Regarding Covid-19

\begin{tabular}{|c|c|c|c|c|}
\hline No & News / Information Title & Date & Category & Source \\
\hline 1 & $\begin{array}{l}\text { Surat Edaran Penolakan Rap- } \\
\text { id Test Majelis Ulama Indone- } \\
\text { sia }\end{array}$ & 26 May 2020 & Hoax & Facebook \\
\hline 2 & $\begin{array}{l}\text { Setiap Hari Puskesmas di Ke- } \\
\text { lapa Gading Rujuk } 10 \text { Pasien } \\
\text { COVID-19 ke Wisma Atlet }\end{array}$ & 3 June 2020 & Misleading & Medcom.id \\
\hline 3 & $\begin{array}{l}\text { Laser dari termometer gun } \\
\text { akan merusak struktur otak }\end{array}$ & 20 July 2020 & Misleading & Facebook \\
\hline 4 & $\begin{array}{l}\text { Jus Jahe dan Lada Hitam } \\
\text { Mampu Sembuhkan Covid-19 }\end{array}$ & 2 August 2020 & Misleading & Facebook \\
\hline 5 & $\begin{array}{l}\text { Seluruh Karyawan Pabrik ES- } \\
\text { EMKA Terkena Corona Dan } \\
\text { Pabrik Diliburkan }\end{array}$ & 6 August 2020 & Misleading & $\begin{array}{l}\text { http://archive.fo/ } \\
\text { CocKg }\end{array}$ \\
\hline 6 & $\begin{array}{l}\text { Pemakaian Masker Menye- } \\
\text { babkan Penyakit Legionnaires }\end{array}$ & 10 August 2020 & Misleading & Facebook \\
\hline 7 & Corona adalah hoaks & 11 August 2020 & Misleading & Instagram \\
\hline 8 & $\begin{array}{l}\text { Air Kelapa Muda, Jeruk Nipis, } \\
\text { dan Garam Obat Covid-19 }\end{array}$ & 16 August 2020 & Misleading & WhatsApp \\
\hline 9 & $\begin{array}{l}\text { Putri Vladimir Putin Mening- } \\
\text { gal Setelah Dosis Kedua Vak- } \\
\text { sin COVID }\end{array}$ & 17 August 2020 & Misleading & Toronto Today \\
\hline 10 & $\begin{array}{l}\text { Tangkapan Layar Penga- } \\
\text { kuan Relawan Suntik Vak- } \\
\text { sin Covid-19 yang Menye- } \\
\text { but Lupa Punya Hutang tapi } \\
\text { Plonga-Plongo", }\end{array}$ & 18 August 2020 & Manipulated & Facebook \\
\hline
\end{tabular}

Source: covid19.go.id

about Covid-19. One is the feeling of panic and emotional conditions reflected in panic buying symptoms, to panic that leads to psychosomatic (conditions or disorders when the mind affects the body, to trigger physical complaints). The spread of hoaxes also exacerbated panic amid the corona pandemic known as an infodemic.

In a condition where the public has flooded with information, the role of broadcasting supervisory institutions, in this case, the Indonesian Broadcasting Commission, is needed to avoid the negative impact of information and news received by the public. According to Law Number 32 of 2002 concerning Broadcasting, broadcasting is the activity of broadcasting broadcasts using broadcasting and/ormeans of transmission on land, at sea, or in space by using a radio frequency spectrum by air, cable, and/or other media to be received simultaneously. Moreover, simultaneously by the public with broadcast receiving devices.

The same law has also stated that the Indonesian Broadcasting Commission's duties and obligations (KPI) are to 
Yadi Supriadi, dkk. The Role of the West Java Indonesian Broadcasting Commission...

guarantee the public to obtain appropriate and correct information by human rights. It is the basis for West Java KPID to consistently supervise broadcast content related to Covid-19 to be genuinely beneficial to the community and not misleading.

Regarding duties and obligations, the West Java KPID, Dedeh Fardiah stated that televisions in Indonesia mostly uses the Network Station System (SJJ). Many people think, for example, TVOne, TransTV, or other television as national television, even though there is only one national television, namely TVRI. However, because of the private television broadcasts to the West Java region, West Java KPID also participates in monitoring activities.

So far, the West Java KPID does not have a unique channel for information about Covid-19, all integrated under the West Java provincial government's auspices through Pikobar (Covid-19 Information \& Coordination Center). However, according to Fardiah, in coordination with Pikobar, West Java KPID continues to carry out its duties as a broadcasting supervisory agency. For example, they coordinate or publish information related to Covid-19, including encouraging how the media plays an active role and does not disturb the atmosphere.

As a broadcasting monitoring agency, West Java KPID also does not calculate how much news and information has spread about Covid-19 because this area is in the Kominfo area. West Java KPID focuses on encouraging broadcasting institutions to always be guided by the Broadcasting Code of Conduct and Broadcast Program Standards (P3SPS), including an appeal always to pay attention to health protocols in every broadcasting program. For example, in a talk show, physical distancing must be considered following the government's efforts to carry out the PSBB. If not, of course, the West Java KPID will immediately give a warning to the media for violating the PSBB rules (Fardiah, 2020).

Furthermore, as an institution under the Central KPI, West Java KPID also reminds the mass media to raise information and news about Covid-19. It is referred to the Central Indonesian Broadcasting Commission Circular Letter Number 123 / K / KPI / 31.2 / 03/2020 concerning Corona Outbreak Broadcasting, which contains the following:

First, report/inform the coronavirus outbreak carefully. It does not speculatively and does not cause public panic in all broadcast programs, including statements from hosts/reporters/ announcers. Using diction (choice of words) and the presenter/reporter/host's presentation tightly and does not appear to be dramatizing or frightening not to cause the public perception that causes panic. Second, delivering that the government has intervened in dealing with the coronavirus outbreak (Covid-19). It has mentioned the Indonesian Ministry of Health's hotline service ( 081212123119 or 021-5210411) or hotline service for each region and referral hospital for handling the coronavirus outbreak in each region. Third, using sources of information about the coronavirus from reliable and confirmed sources and not broadcasting information from social media unless the information has confirmed. Fourth, presenting credible interview sources and delivering positive interview material in discussing the coronavirus outbreak.

Fifth, not mentioning the patient's identity and not exploiting the environment and residents around the patient. Sixth, delivering data on the coronavirus outbreak in a balanced manner. If someone wants to convey the death rate, the cure rate must be followed 
(percentage). Seventh, the show/broadcast PSA (public service advertisements). It has about the coronavirus outbreak. It contains spreading, symptoms, and prevention. Besides, containing the first measures in government and regional services. Eighth, delivering a warning that parties who take advantage of the situation. It has related to the coronavirus outbreak (mask speculators and hand sanitizers) is threatened with six years imprisonment and a maximum fine of IDR 4 billion, as stated in Law no. 24/2007 on disaster management.

The chairperson has seen the high frequency of news and information. They have a different effect on the community. First, a group of people takes the attitude that the researcher can anticipate and stay alert. There is an attitude that the researcher would rather not listen to the news because it will create fear and panic.

Panic or anxiety itself has characterized by worry about unforeseen dangers that lie in the future. Anxiety is a negative emotional state characterized by premonition and somatic tension, such as a racing heart, sweating, difficulty breathing (Annisa and Ifdil, 2016). Anxiety is the ego's function to warn the individual about the possibility of a danger coming to have prepared an appropriate adaptive reaction. Anxiety serves as a mechanism that protects the ego because anxiety signals to us that there is danger. Suppose the right action has not taken; the danger will increase until the ego is defeated (Kumbara, Metra, and Ilham: 2018).

The second type of effect conveyed by the chairperson of the West Java KPID is very obligatory. Information overload is very susceptible to being mixed with hoaxes with vast spread on the timeline and social media. According to Santi Indra Astuti, anti-hoax activist Mafindo (Indonesian Anti-Defamation Society), hoaxes spread quickly due to several factors. First, instrumental factors, namely amplification by social media and digital media. Second, psychological factors, the mental configuration of the present that is different from before. Third, situational factors, when the party is supposed to provide information but is not maximally carrying out its role, or even ignoring it. Finally, the communicators' role is replaced by other parties who sometimes already have agendas for their interests.

As chairman, Fardiah and the West Java KPID team always warned all media under the supervision of the West Java KPID to be careful in delivering news related to Covid-19. According to Fardiah, so far, broadcast media is safe from hoaxes because of its clear structure. However, now is the moment to reach the audience to have more confidence in the media (mainstream media). Fardiah also stated that the panic caused by high consumption of information is an indicator of low literacy. Information that is absorbed just like that without any critical attitude to question its truth will drive the individual toward panic. For the general public, with the demands of life, it is difficult to be more selective and critical. Their focus is on how to earn a living and support their family (Fardiah, 2020).

Therefore, the West Java KPID efforts to prevent public panic during this pandemic have two ways; (1) monitoring and (2) media literacy. Monitoring of broadcast is carried out by the West Java KPD every day for 24 hours. It starts from the recording process, reviewing it. If there is an indication of a violation, a review is carried out by referring to the broadcasting law and then entering the plenary stage; Whether the broadcast violates. The monitoring carried out by the West Java KPID is, of course, so that all broadcast content, including news concerning Covid-19, does not violate the Broadcast Code of Conduct and 
Yadi Supriadi, dkk. The Role of the West Java Indonesian Broadcasting Commission...

Broadcast Program Standards (P3SPS). P3SPS is the result of the agreement of all Regional KPIs / KPIs throughout Indonesia which are stipulated in the KPI Regulation as a guideline for broadcasting institutions in carrying out broadcasting operations which have undergone two changes, first in 2009 and the second in 2012 (Andriansyah, Unde, and Hasrullah: 2018).

According to Luaylik and Hudaya (2018), monitoring of confiscation is about knowing various violations and how to measure the violations to determine the sanctions that will have given. However, several characteristics must have fulfilled. The supervision is in order to run optimally and efficiently. Both in the form of cooperation with broadcasting institutions and conditions for monitoring targets, surveillance activities impact activities' targets.

Meanwhile, the media literacy activities carried out by West Java KPID depart from the enthusiasm outlined in the tagline; "Smart Media, Smart Media." It implemented the active efforts of West Java KPID. To keep reminding the media to be smarter by consistently holding the guidelines for broadcasting behavior. West Java KPID is doing this by traveling around the City / Regency to conduct workshops so that the media is smart in broadcasting broadcasts, does not commit violations, and provides guidance. Meanwhile, media-savvy carried with various West Java KPID programs such as goes to campus. The West Java KPID goes to the village, goes to school, and goes to pesantren to increase media literacy among the community, including West Java KPID in seminar forums (FGD ) regarding broadcasting media during a pandemic. The strategy carried out by KPID West Java at the time of providing literacy was carried out by selecting target nodes, which later on the target nodes would re-disseminate education about media literacy to a broader target (Supratman, 2017).

According to Santi Indra Astuti, media literacy is a form of media education that is good for society. It follows media literacy principles, such as how to access, filter the information, comprehend, analyze, and be part of a good society by being a good citizen. Meanwhile, according to Taufik and Suhaeri (2020), iterative media is used to answer people's increasing views about its effects and the impact arising from the content of mass media, which tends to be harmful and unpredictable.

Entering July 2020, the news and information about Covid-19 decreased along with the stipulation of The Adaptation's status to New Habits (AKB). During the AKB period, Mahi M. Hikmat saw a shift in society towards indifference.

According to him, mass media theories that have tested quantitatively tend to be dominated by the conclusions, quantity, and quality of the frequency of content in the mass media, which broadly determine the influence on humans. The more and better content presented in the mass media, there is a tendency for the higher the level of influence of the content on audience behavior and vice versa. Then Hikmat emphasized that this thesis could be analogous to the presentation of the Covid-19 case content. Regardless of the influence of other aspects, the increase in the positive number of Covid-19 in Indonesia in recent weeks (August 2020) may be related to stopping the presentation of television information.

The analysis presented by Hikmat shows that the level of distribution of information and news about Covid-19 is like the fruit of simalakama; when information is abundant, it creates panic, but vice versa, when there is less information, there is indifference. In line with that, Buana (2020) views that during 
a pandemic, people experience what is called optimism bias.

Optimism bias is a cognitive bias that makes a person believe that they are less likely to experience adverse events. It is also known as unrealistic optimism or comparative optimism. This concept can explain why Indonesians are still not afraid to carry out activities. These are exposed to many people, holidays for example, because they are too confident that corona is not that dangerous. It is because typical Indonesians are relaxed in facing any condition, or believe that God will protect the Indonesian state (Buana, 2020).

\section{CONCLUSION}

Even though the West Java KPID has not found any broadcasting violations related to news and information regarding Coid-19 media, they monitor and literacy are continuously carried. The public remains calm in the face of the pandemic, especially entering September 2020, where new Covid-19 cases have emerged. It is allegedly due to the decline in news content and information about Covid-19, causing the community to start to care less about vigilance and prevention. The West Java KPID also carried out other efforts through socialization. Both through a broadcasting appeal letter during the pandemic, the active role of the West Java KPID through coordinating work with the West Java government, and encouragement for the mass media to continue to be guided by predetermined broadcasting standards.

\section{REFERENCES}

Andriansyah, Unde, Andi Alimuddin., Hasrullah, (2018). Pelanggaran Siaran Televisi Lokal Dan Pemberian Sanksi Oleh Kpid Sulsel Di Kota Makassar, Jurnalisa, Vol. 4 No. 2, November 2018 ; 286-300. http://journal. uinalauddin.ac.id/index.php/jurnalisa/ article/view/6901

Annisa, Dona Fitri., Ifdil, (2016). Konsep Kecemasan (Anxiety) pada Lanjut Usia (Lansia), Konselor, Vol. 5 No 2, June 2016; 93-99, http://ejournal.unp.ac.id/ index.php/konselor/article/view/6480

Ardianto, Elvinaro. (2014). Metodelogi Penelitian untuk Public Relations Kuantitatif dan Kualitatif, Bandung : Simbiosa Rekatama Media.

Buana, Dana Riksa., (2020). Analisis Perilaku Masyarakat Indonesia dalam Menghadapi Pandemi Virus Corona (Covid-19) dan Kiat Menjaga Kesejahteraan Jiwa, Jurnal Sosial dan Budaya Syar-i, Vol 7, No 3 (2020), 217-226, http://journal.uinjkt.ac.id/ index.php/salam/article/view/15082

Cangara, H. (2012). Pengantar Ilmu Komunikasi. Jakarta: PT. Raja Grafindo Persada.

Creswell, John W. (2002), Research Design: Pendekatan Kualitatif, Kuantitatif dan Mixed, Pustaka Pelajar, Yogyakarta.

Hikmat, Mahi M., (2020), Media Massa \& Covid-19, Harian Umum Pikiran Rakyat, 10 Agustus 2020, hal. 15.

Joharudin, Agus., Septiadi, Muhammad Andi., Maharani, Sephia., Aisi, Tarisma Ditya., Nurwahyuningsih, (2020). Panic Syndrom Covid-19 : Penekanan Terhadap Kebijakan Yang Diberikan Pemerintah, Jurnal Perspektif, Vol. 4 No. 1 Mei 2020: 44-53, https://www. perspektif.uinsgd.ac.id/index.php/JP/ article/view/63

Kumbara, Hengki., Metra, Yogi ., Ilham, Zulpikar., (2018) Analisis Tingkat Kecemasan (Anxiety) Dalam Menghadapi Pertandingan Atlet Sepak Bola Kabupaten Banyuasin Pada Porprov 2017, Jurnal Ilmu Keolahragaan, Vol. 17 (2), JuliDesember 2018: 28-35, https://jurnal. unimed.ac.id/2012/index.php/JIK/ article/view/12299

Luaylik, Nur Fathin., Hudaya, Nanik Kusumiati, (2018). Implementasi Fungsi Pengawasan Penyiaran Program Musik Dangdut Oleh KPID Jawa Timur, Jurnal Reformasi, Volume 8 Nomor 2 (2018), 162-177, http:// journal.uinjkt.ac.id/index.php/salam/ 
Yadi Supriadi, dkk. The Role of the West Java Indonesian Broadcasting Commission...

article/view/15082/pdf

Mutmainnah, Nina., (2019). Upaya Pemerintah Mempertahankan Posisi Sebagai Regulator Utama Penyiaran di Indonesia, Jurnal Komunikasi, Vol 14. ,No 1, Oktober 2019, 23-40; https:// journal.uii.ac.id/jurnal-komunikasi/ article/view/13802

Posetti, Julie., Bontcheva, Kalina, (2020), Disinfodemic; Deciphering Covid19 Disinformation, United Nations Educational, Scientific and Cultural Organization, Paris.

Rakhmat, Jalaluddin., Ibrahim, Idi Subandi., (2016), Metode Penelitian Komunikasi, Simbiosa Rekatama Media, Bandung.

Sampurno, Muchammad Bayu Tejo., Kusumandyoko, Tri Cahyo., Islam, Muh Ariffudin., (2020). Budaya Media Sosial, Edukasi Masyarakat dan Pandemi COVID-19, Jurnal Sosial \& Budaya Syar-i, FSH Syarif Hidayatullah, Jakarta, Vol. 7 No. 6, 529-542, :

http://journal.uinjkt.ac.id/index.php/ salam/article/view/15210

Sarwono, Billy K., (2015), Komunikasi Massa, Penerbit Universitas Terbuka, Banten.

Shadiqi, Muhammad Abdan., Hariati, Rima., Hasan, Khaerullah Fadhli Arasy., Noor I'anah, Istiqomah, Wita Al., (2020). Panic Buying Pada Pandemi Covid-19:
Telaah Literatur Dari Perspektif Psikologi, Jurnal Psikologi Sosial, Special Edition COVID-19 Vol. 18, No. xx, xx-xx: http://jps.ui.ac.id/index. php/jps/article/view/221

Supratman, Lucy Pujasari., (2017). Strategi KPID Jawa Barat Dalam Menyosialisasikan Literasi Media, Jurnal Penelitian Komunikasi, Vol. 20 No. 1, Juli 2017: 75-90, https://www.researchgate.net/ publication/318677985_Studi_Kasus_ Strategi_KPID_Jawa_Barat_dalam_ Mensosialisasikan_Literasi_Media

Taufik, Cevi Mochamad, Suhaeri, (2020). Media Literacy in Information Chaos Era: Qualitative Study Bandung Literacy Activist, Jurnal MediaTor, Vol 13 (1), Juni 2020, 132-140, https:// ejournal.unisba.ac.id/index.php/ mediator/article/view/5791

Yin, Robert., (2003), Stud Kasus; Desain dan Metode, Rajawali Press, Bandung.

Yono, Rusmana, Indriya., Noviyanti, Hielda., (2020). Psikoterapi Spiritual dan Pendidikan Islam Dalam Mengatasi dan Menghadapi Gangguan Anciety Disorder di Saat dan Pasca Covid-19, Jurnal Sosial \& Budaya Syar-i, FSH Syarif Hidayatullah, Jakarta, Vol. 7 No. 7, 649-658, : http://journal.uinjkt.ac.id/ index.php/salam/article/view/15801 